\title{
ESTIMASI JARAK GENETIK DAN FAKTOR PEUBAH PEMBEDA RUMPUN KELINCI MELALUI ANALISIS MORFOMETRIK
}

\author{
(Genetic Distance Estimation and Variable Differential Factor Through Analysis of \\ Morphometrics on Rabbit)
}

\author{
Ukurta Pinem $^{1}$, Hamdan ${ }^{2}$, dan Nevy Diana Hanafi \\ 1. Mahasiswa Program Studi Peternakan Fakultas Pertanian Universitas Sumatera Utara \\ 2. Staff Pengajar Program Studi Peternakan Fakultas Pertanian Universitas Sumatera Utara
}

\begin{abstract}
The research aims to determine estimation of mahalanobis genetic distance. There was conducted in farmer groups Rehna Latersia Berastagi (North Sumatra). The objectives of this research using 227 heads rabbit of 20 strain rabbit, strain were analized Rex, English Spot (ES), English Angora (AI), Angora Francis (AF), Vlaamse Reus (VR), Lyon, Lop, Dwarfth, Lilo (Lyon x Lop), Loplylo (Local Lop x Lilo), Lyplyp (F1 Lilo), Anglolylo (Local Angora x Lilo), Loes (Local x ES), Lela (Loes x lyang), Lorex (Local x Rex), Lovla (Local $x$ VR), Lilolop (Lilo x Lop), Lyalya (F1 lyang), Angrexlya ((Angora x Rex) x lyang), and lyang (Lyon $x$ Angora). Data were collected consist of the head (length, width), ears (length, width), chest (girth, deep, wide), long bones (radius-ulna, humerus, tibia, femur, spine), wide hips, long hair (back, hips, head, between the ears, the head between the eyes, stomach). The results showed that the rabbit ES, VR, Lovla, and Loes have a larger body size, while AI and AF have longer hair than the other rabbit strains, fenogram tree formed four groups, the far genetic distance showed between VR rabbit by Dwarfth (8,24), ES by Dwarfth (8,28), the close genetic distance showed Loplylo by Lilo (1,31), and Loplylo by Lop (1.66). Results of canonical analysis showed that the most discriminant variables were obtained by fur length type on (abdomen, hips, between the eyes, back) for first canonical, and length (head of the humerus bone, and ear) for second canonical. The conclusion of this study is the rabbit with the same purpose showed relative high on mixture value, and have relative similar morphometrics.
\end{abstract}

Keywords : Rabbit, Genetic Distance, Morphometrics

\begin{abstract}
ABSTRAK
Penelitian ini bertujuan untuk mengetahui dan menduga jarak genetik mahalonobis diantara rumpun kelinci. Penelitian dilakukan di kelompok tani Rehna Latersia Berastagi (Sumatera Utara) menggunakan 227 ekor dari 20 rumpun kelinci yaitu kelinci Rex, English Spot (ES), Angora Inggris (AI), Angora Francis (AF), Vlaamse Reus (VR), Lyon, Lop, Dwarfth, Lilo (Lyon x Lop), Loplylo (Lokal Lop x Lilo), Lyplyp (F1 Lilo), Anglolylo (Anggora Lokal x Lilo), Loes (Lokal x ES), Lela (Loes x Lyang), Lorex (Lokal x Rex), Lovla (Lokal x VR), Lilolop (Lilo x Lop), Lyalya (F1 Lyang), Angrexlya ((Anggora x Rex) x Lyang), dan Lyang (Lyon x Anggora). Pengambilan data dilakukan pada kepala (panjang, lebar), telinga (panjang, lebar), dada (lingkar, dalam, lebar), panjang tulang (radius-ulna, humerus, tibia, femoris, punggung), lebar pinggul, panjang bulu (punggung, pinggul, kepala diantara telinga, kepala diantara mata dan perut). Hasil penelitian menunjukkan bahwa kelinci ES, VR, Lovla dan Loes memiliki ukuran tubuh lebih besar sedangkan AI dan AF memiliki rambut yang lebih panjang dibandingkan dengan galur kelinci lainnya, pohon fenogram membentuk empat kelompok kekerabatan, jarak genetik paling jauh ditunjukkan antara kelinci VR dengan Dwarfth $(8,24)$, ES dengan Dwarfth $(8,28)$, jarak genetik dekat ditunjukkan Loplylo dengan Lilo $(1,31)$, dan Loplylo dengan Lop $(1,66)$. Hasil analisis kanonik memperlihatkan bahwa peubah fenotipik pembeda jenis kelinci adalah panjang bulu (perut, pinggul,diantara mata, punggung) pada kanonik pertama dan panjang (kepala, tulang humerus dan telinga) pada kanonik kedua. Kesimpulan dari penelitian ini adalah kelinci dengan tujuan produksi yang sama menunjukkan nilai campuran antar rumpun relatif tinggi dan ukuran fenotipik yang relatif sama.
\end{abstract}

Kata kunci: Kelinci, Jarak Genetik, Morfometrik. 


\section{PENDAHULUAN}

Bidang peternakan pada dewasa ini memegang peranan penting dalam pembangunan nasional Indonesia sebagai sumber pendapatan bagi masyarakat terutama pada masyarakat menegah kebawah karena biaya yang dibutuhkan untuk usaha relatif kecil dibandingkan dengan usaha-usaha lainnya, salah satunya adalah usaha ternak kelinci.

Secara umum kelinci memiliki potensi biologis dan ekonomi yang tinggi sebagai penghasil daging, dan kulit-rambut bermutu, dan juga sebagai hewan kesayangan (hias) (Raharjo, 2001). Kelinci mampu tumbuh dan berkembang biak dari hijauan, limbah pertanian dan limbah pangan serta dapat dipelihara pada skala rumah tangga atau skala kecil (Brahmantiyo dkk, 2006).

Untuk meningkatkan produksi dan mencapai kualitas genetik ternak seperti yang diharapkan merupakan faktor penting dan dapat dilakukan melalui seleksi dan persilangan (Hamdan, 2005). Melindungi ternak turunan murni sebagai plasma nutfah juga tidak kalah penting. Sehingga diperlukan informasi mengenai inventarisasi dan karakterisasi dari berbagai rumpun yang telah ada. Karakterisasi pada ternak dapat digunakan sebagai kriteria seleksi yang selanjutnya dapat digunakan sebagai acuan untuk persilangan untuk memperoleh kelinci yang mampu berproduksi tinggi dan mampu beradaptasi dengan lingkungan tropis.

Kawin silang atau cross breeding biasanya dilakukan dengan tujuan meningkatkan (memanfaatkan) heterozigositas dan mengkombinasikan sifat-sifat baik antara bangsa yang berbeda (Martojo, 1992) Croos breeding berpengaruh dalam meningkatkan proprsi gen-gen yang heterzigot dan menurunkan proporsi gen yang homzigot. Derajat heterozigositas tergantung dari hubungan kekerabatan ternak yang disilangkan. Jika ternak yang tidak memiliki hubungan keluarga disilangkan maka keturunannya cenderung menampilkan performa yang lebih dari rataan performa tetuanya. Fenomena ini disebut dengan hybrid vigor yang dapat diukur secara kuantitatif, disebut dengan heterosis. Heterosis dikatakan ada jika rataan performa hasil persilangan melebihi rataan tetua yang purebred (Noor, 2004).

Pengukuran pertulangan pada kelinci juga telah dilaporkan oleh banyak peneliti sebelumnya khususnya di Indonesia diantaranya Lidia Fafarita (2006) yang membandingkan tiga rumpun kelinci di kabupaten Magelang, Brahmantiyo et al., (2006) yang membandingkan enam rumpun kelinci yang berasal dari dua wilayah yaitu Bogor dan Magelang. Diperoleh hasil bahwa kelinci yang dikembangkan dengan tujuan produksi yang sama pada satu populasi memiliki jarak genetik yang relatif dekat dengan adanya nilai campuran antar galur kelinci tersebut. Jarak genetik merupakan tingkat perbedaan gen (perbedaan genom) di antara suatu 
populasi atau spesies (Nei, 1987).

Ukuran panjang bulu pada kelinci merupakan salah satu sifat kuantitatif, yang dipengaruhi oleh bangsa/galur kelinci atau genetik dan pengaruh lingkungan. Galur kelinci yang berbeda dalam populasi pemeliharaan yang sama dapat diasumsikan mendapat perlakuan lingkungan (pakan, menejemen pemeliharaan dan ilklim) yang sama pula. Oleh karena itu penulis tertarik untuk melakukan penelitian serupa dengan jumlah rumpun kelinci yang lebih banyak yang terdiri dari ras murni dan silangan dan di daerah yang berbeda pula yaitu di Berastagi dan dengan tambahan peubah ukuran panjang bulu dalam mengestimasi jarak genetik antar galur dalam populasi sehingga dapat memberikan manfaat untuk tindakan pemuliaan khususnya untuk menentukan pola perkawinan.

\section{BAHAN DAN METODE PENELITIAN}

\section{Lokasi dan Waktu Penelitian}

Penelitian ini dilaksanakan di Jalan Udara, Gang Rukun, Berastagi, Kabupaten Karo, Sumatera Utara (Peternakan kelinci kelompok tani Rehna Latersia). Lokasi berada diketinggian $1368 \mathrm{~m}$ diatas permukaan laut, dengan suhu rata-rata $15-20^{\circ} \mathrm{C}$. Penelitian dilaksanakan mulai bulan Agustus hingga Oktober 2013.

\section{Bahan dan Alat Penelitian}

Keseluruhan ternak yang diamati 227 ekor yang berumur $\geq 1$ tahun. Data diperoleh dari kelinci jantan dan betina dan digabungkan karena menurut Taylor et al (1977) tidak terdapat sexual-dimorphism, yang terdiri dari : 34 ekor AI, 8 ekor AF, 13 ekor Lyon, 6 ekor Lop, 12 ekor VR, 8 ekor ES, 36 ekor Rex, 3 ekor Dwarfth, 28 ekor Lyang (Lyon x Anggora), 6 ekor Lyalya (F1 Lyang), 27 ekor Lilo (Lyon x Lop), 4 ekor Lyplyp (F1 Lilo) , 6 ekor Loplylo (Lokal Lop x Lilo), 4 ekor Lilolop (Lilo x Lop), 6 ekor Anglolylo (Anggora Lokal x Lilo), 10 ekor Lovla (Lokal x VR), 8 ekor Loes (Lokal x ES), 9 ekor Lorex (Lokal x Rex), 4 ekor Angrexlya ((Anggora x Rex) x Lyang), dan 3 ekor Lela (Loes x Lyang). Alat yang digunakan terdiri atas meteran kain bersekala terkecil $1 \mathrm{~mm}$ dan jangka sorong digital berskala $15 \mathrm{~cm}$ dengan skala terkecil 0,01 mm untuk mengukur tubuh kelinci, timbangan elektrik dengan kepekaan 1 gram untuk menimbang bobot badan kelinci, Alat tulis dan lembar data digunakan untuk mencatat hasil pengamatan dan pengukuran, perangkat lunak SAS (Statistical Analysis System) dan MEGA (Molekuler Evolusioner Genetic Analysis) digunakan untuk menganalisis data. 


\section{Analisis Data}

\section{Uji Duncan}

Uji jarak ganda Duncan atau Uji Duncan Multiple Range Test (DMRT) untuk mengetahui jenis terbaik berdasarkan rankingnya. Perhitungan dilakukan dari hasil rata-rata setiap perlakuan. Uji ini juga dilakukan untuk mengetahui adanya perbedaan dari pemberian perlakuan yang dilakukan uji F. Uji Duncan juga digunakan untuk melihat adanya pengaruh antar perlakuan yang diuji Uji Duncan atau juga dikenal dengan istilah Duncan Multiple Range Test (DMRT) memiliki nilai kritis yang tidak tunggak tetapi mengikuti urutan rata -rata yang dibandingkan. Nilai kritis uji Duncan dinyatakan dalam nilai least significant range (Sarvia, 2012) :

$S e=\sqrt{\frac{\mathrm{M} \mathrm{se}}{\mathrm{r}}} \quad R p=q_{\propto} S_{e}$

Di mana :

Rp : wilayah nyata terkecil Duncan

$\mathrm{q}_{\alpha}$ : sebaran wilayah di student kan untuk uij Duncan pada $\alpha, \mathrm{p}$ dan dbf

$\mathrm{p}$ : nomor urutan rata - rata dari nilai terkecil $(\mathrm{p}=2,3,4 \ldots, \mathrm{t}$

\section{Analisis Diskriminan}

Perbedaan ukuran dari bagian tubuh yang diamati dianalisis dengan menggunakan General Linear Models (GLM) menurut Statistics Analytical System (SAS 1985). Penentuan hubungan kekerabatan kelinci di dalam dan antar populasi menggunakan fungsi diskriminan sederhana Manly (1989) fungsi diskriminan yang digunakan melalui pendekatan jarak Mahalanobis seperti yang dijelaskan oleh Nei (1987) matriks ragam peragam antara peubah dari masing-masing galur kelinci yang diamati digabungkan menjadi sebuah matriks. Matriks gabungan dapat dijelaskan ke dalam bentuk berikut :

$\mathrm{C}=\left[\begin{array}{cccc}\mathrm{C}_{11} & \mathrm{C}_{12} & \cdots & \mathrm{C}_{1 \mathrm{p}} \\ \mathrm{C}_{21} & \mathrm{C}_{22} & \ldots & \mathrm{C}_{2 \mathrm{P}} \\ \cdots & \cdots & \cdots & \ldots \\ \Gamma_{-} & C_{-} & \cdots & \Gamma_{--}\end{array}\right]$

Jarak genetik Mahalanobis sebagai ukuran jarak kuadrat genetik minimum yang digunakan sesuai petunjuk Nei (1987) adalah sebagai berikut : 


$$
D^{2}(i, j)=(\bar{X} i-\bar{X} j) C^{-1}(\bar{X} i-\bar{X} j)
$$

Keterangan :

$\mathrm{D}^{2}(\mathrm{i}, \mathrm{j})=$ Nilai statistik Mahalanobis sebagai jarak kuadrat antar galur kelinci ke-I dan galur kelinci ke-j

$\mathrm{C}^{-1} \quad=$ Kebalikan matrik gabungan ragam peragam antar peubah

$\bar{X}_{i} \quad=$ Vektor nilai rataan pengamatan dari galur kelinci ke-i pada masing- masing peubah

$\bar{X}_{i} \quad=$ Vektor nilai rataan pengamatan dari galur kelinci ke-j pada masing-masing peubah

Untuk membantu analisis statistik Mahalonobis digunakan paket program SAS (SAS, 1985) dengan menggunakan prosedur Proc Discrim. Dari hasil perhitungan jarak kuadrat tersebut kemudian dilakukan pengakaran terhadap hasil jarak genetik yang didapat. Hasil pengakaran terhadap hasil jarak genetik dianalisis menggunakan perangkat lunak MEGA seperti petunjuk Kumar et al., (2001) untuk memperoleh pohon fenogram. Teknik pembuatan pohon fenogram dilakukan dengan metoda UPGMA (Unweight Pair Group Method with Arithmetic) dengan asumsi bahwa laju evolusi antar galur/kelompok kelinci adalah sama. Beberapa keuntungan yang didapat dari penggunaan teknik ini dikemukakan oleh Kumar et al., (2001) karena sederhana dan berguna pada kondisi kelompok yang relatif stabil.

Analisis canonical dilakukan untuk menentukan peta penyebaran galur kelinci dan nilai kesamaan dan nilai campuran di dalam dan diantara galur/ kelompok kelinci (Manly 1989). Analisis ini juga dipakai untuk menentukan beberapa peubah yang memiliki pengaruh kuat terhadap terjadinya pengelompokkan galur kelinci (pembeda galur kelinci). Prosedur analisis dengan menggunakan Proc Candisk dari SAS (SAS, 1985).

\section{Peubah yang Diamati}

Peubah karakteristik morfometrik diperoleh dengan melakukan pengukuran pada bagian-bagian tubuh setiap individu kelinci (Brahmanyiyo, 2006) yang meliputi:

a. Panjang kepala (PK) adalah jarak antara titik tertinggi (pangkal telinga) sampai titik terdepan tengkorak (ujung tulang hidung).

b. Lebar kepala (LK) adalah jarak antara titik penonjolan tengkorak kiri dan kanan.

c. Tinggi kepala (TK) adalah jarak antara titik tertinggi tengkorak sampai titik terendah rahang bawah.

d. Lingkar dada (LD) adalah lingkar rongga dada di belakang sendi bahu (os scapula). 
e. Dalam dada (DD) adalah jarak antara titik tertinggi pundak dan tulang dada.

f. Lebar dada (LeD) adalah jarak antara kerangka dada dibelakang skapula kanan dan scapula kiri.

g. Panjangnya tulang Radius-ulna (R-U) adalah panjang kaki depan bawah.

h. Panjangnya tulang Humerus (Hu) adalah Panjang kaki depan atas.

i. Panjang tulang Tibia (Ti) adalah panjang kaki bawah belakang.

j. Panjangnya tulang Femoris (Fe) adalah panjang kaki belakang atas.

k. Panjang tulang punggung (PP) adalah diukur dari tulang punggung pertama hingga tulang pangkal ekor.

1. Lebar tulang panggul (LP) adalah jarak antara tulang pangkal paha kiri dan pangkal paha kanan.

m. Panjang daun telinga (DT) adalah jarak antara pangkal daun telinga sampai titik ujung telinga.

n. Lebar daun telinga (LT) adalah jarak antara dua titik terluar daun telinga secara tegak lurus terhadap panjang telinga.

o. Bobot badan (BB), penimbangan dilakukan satu persatu dan diusahakan tenang.

Peubah karakteristik panjang rambut diperoleh dengan mengukur rambut pada bagian tubuh yang meliputi:

a. Panjang rambut punggung (BP) pengukuran dilakukan dengan cara melakukan pencabutan pada beberapa helai rambut yang berada pada bagian punggung kemudian diukur panjang rata-rata nya(Budi et al, 2005).

b. Panjang rambut pinggul (BPG) pengukuran dilakukan dengan cara melakukan pencabutan pada beberapa helai rambut yang berada pada bagian pinggul kemudian diukur panjang rata-ratanya (Budi et al, 2005).

c. Panjang rambut perut (BPRT) pengukuran dilakukan dengan cara melakukan pencabutan pada beberapa helai rambut yang berada pada bagian perut kemudian diukur panjang rataratanya (Budi et al, 2005).

d. Panjang rambut kepala diantara telinga (BTT), pengukuran dilakukan dengan cara melakukan pencabutan pada beberapa helai rambut yang berada pada bagian kepala diantara telinga kemudian diukur panjang rata-ratanya.

e. Panjang rambut kepala diantara mata (BTK), pengukuran dilakukan dengan cara melakukan pencabutan pada beberapa helai rambut yang berada pada kepala diantara mata kemudian diukur panjang rata-ratanya. 


\section{HASIL DAN PEMBAHASAN}

\section{Karakteristik ukuran tubuh}

Hasil perhitungan uji Duncan kelinci penelitian disajikan pada Tabel 1a dan 1b. Data ukuran tubuh hanya memberikan informasi mengenai perbedaan dan persamaan pada ukuran kepala (panjang, lebar, tinggi), telinga (panjang, lebar), dada (dalam, lebar, lingkar), panjang tulang tibia, panjang tulang femur, panjang tulang humerus, panjang tulang radius-ulna, panjang tulang punggung, lebar tulang panggul dan bobot badan.

Tabel 1a. Karakteristik ukuran tubuh kelinci ES,VR, Loes, Lovla, AF, Lela, AI, Lyang, Loplylo,Lilolop

\begin{tabular}{|c|c|c|c|c|c|c|c|c|c|c|}
\hline Peubah & ES & VR & Loes & Lovla & $\overline{\mathrm{AF}}$ & Lela & $\overline{\mathrm{AI}}$ & Lyang & Loplylo & Lilolop \\
\hline$\overline{P K}$ & $14.19^{\mathrm{A}}$ & $13.89^{\mathrm{A}}$ & $12.86^{\mathrm{B}}$ & $12.53^{\mathrm{BC}}$ & $12.30^{\mathrm{BCD}}$ & $12.30^{\mathrm{BCD}}$ & $12.23^{\mathrm{BCDE}}$ & $12.16^{\mathrm{BCDEF}}$ & $12.10^{\mathrm{CDEF}}$ & $12.07^{\mathrm{CDEF}}$ \\
\hline LK & $4.62^{\mathrm{AB}}$ & $4,65^{\mathrm{A}}$ & $4.43^{\mathrm{ABCD}}$ & $4.32^{\mathrm{CD}}$ & $4.37^{\mathrm{ABC}}$ & $4.26^{\mathrm{D}}$ & $4.38^{\mathrm{BCD}}$ & $4.32^{\mathrm{CD}}$ & $4.31^{\mathrm{CD}}$ & $4.30^{\mathrm{CD}}$ \\
\hline TK & $5.84^{\mathrm{AB}}$ & $6.08^{\mathrm{A}}$ & $5.57^{\mathrm{BC}}$ & $5.43^{\mathrm{CDEF}}$ & $5.45^{\mathrm{CDEF}}$ & $5.35^{\mathrm{CDEF}}$ & $5.35^{\mathrm{CDEF}}$ & $5.35^{\mathrm{CDEF}}$ & $5.35^{\mathrm{CDEF}}$ & $5.47^{\mathrm{CDE}}$ \\
\hline LD & $28.20^{\mathrm{AB}}$ & $29.45^{\mathrm{A}}$ & $27.49^{\mathrm{ABCD}}$ & $27^{\mathrm{BCDE}}$ & $26.44^{\mathrm{BCDEF}}$ & $26.30^{\mathrm{BCDEF}}$ & $25.48^{\mathrm{DEF}}$ & $25.32^{\mathrm{DEF}}$ & $25.35^{\mathrm{DEF}}$ & $25.85^{\mathrm{CDEF}}$ \\
\hline $\mathrm{DD}$ & $8.33^{\mathrm{B}}$ & $9.34^{\mathrm{A}}$ & $8.17^{\mathrm{BC}}$ & $7.86^{\mathrm{BCD}}$ & $7.69^{\mathrm{BCD}}$ & $7.66^{\mathrm{BCDE}}$ & $7.73^{\mathrm{BCD}}$ & $7.58^{\mathrm{BCDE}}$ & $7.53^{\mathrm{CDEF}}$ & $7.40^{\mathrm{DEF}}$ \\
\hline LeD & $6.70^{\mathrm{ABCD}}$ & $7.23^{\mathrm{A}}$ & $6.83^{\mathrm{ABC}}$ & $6.28^{\mathrm{CDE}}$ & $6.25^{\mathrm{CDE}}$ & $6.17^{\mathrm{CDE}}$ & $5.99^{\mathrm{E}}$ & $6.20^{\mathrm{CDE}}$ & $6.44^{\mathrm{BCDE}}$ & $7.11^{\mathrm{AB}}$ \\
\hline $\mathrm{R}-\mathrm{U}$ & $8.84^{\mathrm{AB}}$ & $9.28^{\mathrm{A}}$ & $8.65^{\mathrm{ABC}}$ & $8.40^{\mathrm{BCDE}}$ & $8.08^{\mathrm{CDEF}}$ & $7.93^{\mathrm{DEF}}$ & $8.42^{\mathrm{BCD}}$ & $8.27^{\mathrm{BCDE}}$ & $8.38^{\mathrm{BCDE}}$ & $7.72^{\mathrm{EFG}}$ \\
\hline $\mathrm{Hu}$ & $10.18^{\mathrm{AB}}$ & $10.56^{\mathrm{A}}$ & $9.86^{\mathrm{BC}}$ & $9.57^{\mathrm{BCD}}$ & $9.31^{\mathrm{CDEF}}$ & $8.96^{\mathrm{DEF}}$ & $9.50^{\mathrm{CD}}$ & $9.14^{\mathrm{DEF}}$ & $9.26^{\mathrm{CDEF}}$ & $8.70^{\mathrm{F}}$ \\
\hline $\mathrm{Ti}$ & $14.74^{\mathrm{A}}$ & $13.91^{\mathrm{AB}}$ & $13.09^{\mathrm{BC}}$ & $12.82^{\mathrm{CD}}$ & $12.51^{\mathrm{CDEF}}$ & $12.56^{\mathrm{CDE}}$ & $12.92^{\mathrm{BC}}$ & $12.55^{\mathrm{CDEF}}$ & $11.58^{\mathrm{FGE}}$ & $12.82^{\mathrm{CD}}$ \\
\hline $\mathrm{Fe}$ & $9.93^{\mathrm{AB}}$ & $10.50^{\mathrm{A}}$ & $9.73^{\mathrm{BC}}$ & $9.66^{\mathrm{BCD}}$ & $9.87^{\mathrm{AB}}$ & $10.03^{\mathrm{AB}}$ & $9.63^{\mathrm{BCD}}$ & $9.39^{\mathrm{BCDE}}$ & $9.08^{\mathrm{CDEF}}$ & $8.70^{\mathrm{F}}$ \\
\hline PP & $40.99^{\mathrm{AB}}$ & $41.54^{\mathrm{A}}$ & $39.08^{\mathrm{ABC}}$ & $37.75^{\mathrm{ABCD}}$ & $31.81^{\mathrm{EF}}$ & $35.47^{\mathrm{CDEF}}$ & $36.20^{\mathrm{BCDE}}$ & $33.48^{\mathrm{DEF}}$ & $34.81^{\mathrm{CDEF}}$ & $34.57^{\mathrm{CDEF}}$ \\
\hline LP & $6,19^{\mathrm{AB}}$ & $6.57^{\mathrm{A}}$ & $6.16^{\mathrm{BC}}$ & $5.75^{\mathrm{DEFGH}}$ & $5.85^{\mathrm{BCDEF}}$ & $5.58^{\mathrm{EFGHI}}$ & $5.63^{\text {DEFGH }}$ & $5.75^{\mathrm{DEFGH}}$ & $5.74^{\mathrm{DEFGH}}$ & $5.84^{\mathrm{BCDEFG}}$ \\
\hline DT & $14.08^{\mathrm{A}}$ & $13.82^{\mathrm{A}}$ & $12.71^{\mathrm{B}}$ & $12.01^{\mathrm{BC}}$ & $11.11^{\mathrm{DE}}$ & $10.67^{\mathrm{E}}$ & $11.85^{\mathrm{CD}}$ & $11.20^{\mathrm{CDE}}$ & $11.35^{\mathrm{CDE}}$ & $11.90^{\mathrm{BCD}}$ \\
\hline LT & $6.60^{\mathrm{A}}$ & $6.51^{\mathrm{AB}}$ & $6.03^{\mathrm{BC}}$ & $5.44^{\mathrm{DE}}$ & $5.24^{\mathrm{E}}$ & $5.40^{\mathrm{DE}}$ & $5.65^{\mathrm{CDE}}$ & $5.46^{\mathrm{DE}}$ & $5.55^{\mathrm{CDE}}$ & $5.42^{\mathrm{DE}}$ \\
\hline BB & $3.66^{\mathrm{A}}$ & $3.81^{\mathrm{A}}$ & $3.25^{\mathrm{B}}$ & $2.77^{\mathrm{C}}$ & $2.70^{\mathrm{CD}}$ & $2.33^{\mathrm{DEFG}}$ & $2.51^{\mathrm{CDEF}}$ & $2.51^{\mathrm{CDEF}}$ & $2.58^{\mathrm{CDEF}}$ & $2.52^{\mathrm{CDEF}}$ \\
\hline
\end{tabular}

Keterangan: Huruf superskrip yang berbeda pada baris yang sama, berbeda nyata $(\mathrm{P}<0,05)$.

Uji Duncan terhadap rataan setiap ukuran tubuh kelinci menunjukkan bahwa kelinci ES dan VR adalah jenis kelinci yang lebih besar dibandingkan dengan jenis kelinci lain terlihat dari notasi huruf pada ukuran rata-rata setiap peubah yang dengan lebih banyak menunjukkan notasi huruf A dan B pada setiap peubah, kedua galur kelinci ini secara genetik merupakan kelinci tipe besar yang sering dikembangkan dengan tujuan produksi daging hal ini sesuai dengan pernyataan Sarwono (2002) yang menyatakan kelinci ES sering diternakkan untuk menghasilkan daging dengan karkas yang banyak. Begitupun juga dengan kelinci VR yang menurut Mahalovich (2004) merupakan kelinci tipe besar dengan bentuk tubuh yang memanjang dengan perkembangan otot yang baik dengan bagian dari pinggang dan kaki belakang terlihat lebar dan besar. Ukuran dan bentuk tubuh 
kelinci Loes, Lovla dan Lela yang merupakan keturunan dari kelinci ES (Loes dan Lela) dan keturunan VR (Lovla) juga mempelihatkan ukuran yang tinggi dan relatif. menyerupai ukuran tetuanya meskipun pada beberapa peubah berbeda dari tetuanya dengan kata lain adanya keragaman, keragaman sifat morfologis dapat terjadi karena adanya perkawinan silang dan mutasi akibat seleksi (Falconer dan Mackay, 1996).

Tabel 1b.Karakteristik ukuran tubuh kelinci Lyalya, Lop, Lilo, Angrexlya, Lyon, Lyplyp, Lorex, Rex, Anglolylo, Dwarfth.

\begin{tabular}{|c|c|c|c|c|c|c|c|c|c|c|}
\hline Peubah & Lyalya & Lop & Lilo & Angrexlya & Lyon & Lyplyp & Lorex & Rex & Anglolylo & Dwarfth \\
\hline PK & $12.05^{\mathrm{CDEF}}$ & $11.93^{\mathrm{CDEFG}}$ & $11.91^{\mathrm{CDEFG}}$ & $11.80^{\mathrm{DEFG}}$ & $11.78^{\mathrm{DEFG}}$ & $11.67^{\mathrm{DEFG}}$ & $11.58^{\mathrm{EFGH}}$ & $11.49^{\mathrm{FGH}}$ & $11.33^{\mathrm{GH}}$ & $11.10^{\mathrm{H}}$ \\
\hline LK & $4.35^{\mathrm{CD}}$ & $4.38^{\mathrm{BCD}}$ & $4.30^{\mathrm{CD}}$ & $4.36^{\mathrm{CD}}$ & $4.26^{\mathrm{D}}$ & $4.38^{\mathrm{BCD}}$ & $4.29^{\mathrm{CD}}$ & $4.28^{\mathrm{CD}}$ & $4.28^{\mathrm{CD}}$ & $3.95^{\mathrm{E}}$ \\
\hline TK & $5.22^{\mathrm{EF}}$ & $5.44^{\mathrm{CDEF}}$ & $5.31^{\mathrm{CDEF}}$ & $5.20^{\mathrm{EF}}$ & $5.24^{\mathrm{DEF}}$ & $5.51^{\mathrm{CD}}$ & $5.40^{\mathrm{CDEF}}$ & $5.21^{\mathrm{EF}}$ & $5.15^{\mathrm{F}}$ & $4.75^{\mathrm{G}}$ \\
\hline LD & $25.45^{\mathrm{DEF}}$ & $25.46^{\mathrm{DEF}}$ & $25.76^{\mathrm{CDEF}}$ & $25.17^{\mathrm{EF}}$ & $25.61^{\mathrm{CDEF}}$ & $25.65^{\mathrm{CDEF}}$ & $25.18^{\mathrm{EF}}$ & $26.21^{\mathrm{BCDEF}}$ & $24.38^{\mathrm{F}}$ & $27.70^{\mathrm{ABC}}$ \\
\hline DD & $7.85^{\mathrm{BCD}}$ & $7.72^{\mathrm{BCD}}$ & $7.38^{\mathrm{DEF}}$ & $6.93^{\mathrm{EF}}$ & $7.30^{\mathrm{DEF}}$ & $7.39^{\mathrm{DEF}}$ & $7.46^{\mathrm{CDEF}}$ & $7.56^{\mathrm{CDE}}$ & $7.39^{\mathrm{DEF}}$ & $6.79^{\mathrm{F}}$ \\
\hline LeD & $6.56^{\mathrm{ABCDE}}$ & $6.09^{\mathrm{DE}}$ & $6.46^{\mathrm{BCDE}}$ & $6.09^{\mathrm{DE}}$ & $6.25^{\mathrm{CDE}}$ & $6.74^{\mathrm{ABCD}}$ & $6.36^{\mathrm{CDE}}$ & $6.01^{\mathrm{E}}$ & $6.15^{\mathrm{DE}}$ & $5.27^{\mathrm{F}}$ \\
\hline $\mathrm{R}-\mathrm{U}$ & $8.38^{\mathrm{BCDE}}$ & $8.03^{\mathrm{CDEF}}$ & $8.06^{\mathrm{CDEF}}$ & $8.17^{\mathrm{BCDE}}$ & $8.19^{\mathrm{BCDE}}$ & $8.32^{\mathrm{BCD}}$ & $7.46^{\mathrm{FG}}$ & $7.90^{\mathrm{DEF}}$ & $7.85^{\mathrm{DEF}}$ & $7.10^{\mathrm{G}}$ \\
\hline $\mathrm{Hu}$ & $9.38^{\mathrm{CDE}}$ & $9.05^{\mathrm{DEF}}$ & $8.73^{\mathrm{F}}$ & $9.27^{\mathrm{CDEF}}$ & $9,00^{\mathrm{DEF}}$ & $9.05^{\mathrm{DEF}}$ & $9.05^{\mathrm{DEF}}$ & $8.82^{\mathrm{EF}}$ & $8.83^{\mathrm{EF}}$ & $7.70^{\mathrm{G}}$ \\
\hline $\mathrm{Ti}$ & $12.76^{\mathrm{CD}}$ & $11.55^{\mathrm{FG}}$ & $11.74^{\mathrm{FGE}}$ & $12.42^{\mathrm{CDEF}}$ & $12.41^{\mathrm{CDEF}}$ & $11.87^{\mathrm{DEFG}}$ & $11.83^{\mathrm{DEFG}}$ & $11.82^{\mathrm{DEFG}}$ & $11.28^{\mathrm{GH}}$ & $10.46^{\mathrm{H}}$ \\
\hline $\mathrm{Fe}$ & $9.20^{\mathrm{CDEF}}$ & $8.96^{\mathrm{EF}}$ & $9.03^{\mathrm{DEF}}$ & $9.05^{\mathrm{DEF}}$ & $9.21^{\mathrm{CDEF}}$ & $9.15^{\mathrm{CDEF}}$ & $9.10^{\mathrm{CDEF}}$ & $9.20^{\mathrm{CDEF}}$ & $9.05^{\mathrm{DEF}}$ & $7.96^{\mathrm{G}}$ \\
\hline PP & $31.21^{\mathrm{F}}$ & $33.96^{\mathrm{DEF}}$ & $35.01^{\mathrm{CDEF}}$ & $35.90^{\mathrm{CDEF}}$ & $35.50^{\mathrm{CDEF}}$ & $35.07^{\mathrm{CDEF}}$ & $35.78^{\mathrm{CDEF}}$ & $34.54^{\mathrm{CDEF}}$ & $35^{\mathrm{CDEF}}$ & $32.93^{\mathrm{DEF}}$ \\
\hline LP & $5.97^{\mathrm{BCD}}$ & $5.49^{\mathrm{FGHI}}$ & $5.67^{\mathrm{DEFGH}}$ & $5.59^{\mathrm{DEFGHI}}$ & $5.54^{\mathrm{FGHI}}$ & $5.93^{\mathrm{BCDE}}$ & $5.80^{\mathrm{CDEFG}}$ & $5,39^{\mathrm{HI}}$ & $5.46^{\mathrm{GHI}}$ & $5.22^{\mathrm{I}}$ \\
\hline DT & $11.78^{\mathrm{CD}}$ & $11.78^{\mathrm{CD}}$ & $11.26^{\mathrm{CDE}}$ & $10.77^{\mathrm{E}}$ & $11.36^{\mathrm{CDE}}$ & $11.15^{\mathrm{DE}}$ & $10.86^{\mathrm{E}}$ & $10.57^{\mathrm{E}}$ & $11.25^{\mathrm{CDE}}$ & $8.60^{\mathrm{F}}$ \\
\hline LT & $5.634^{\mathrm{CDE}}$ & $5.73^{\mathrm{CD}}$ & $5.45^{\mathrm{DE}}$ & $5.20^{\mathrm{E}}$ & $5.56^{\mathrm{CDE}}$ & $5.25^{\mathrm{DE}}$ & $5.24^{\mathrm{DE}}$ & $5.26^{\mathrm{DE}}$ & $5.30^{\mathrm{DE}}$ & $4.66^{\mathrm{F}}$ \\
\hline BB & $2.69^{\mathrm{CDE}}$ & $2.30^{\mathrm{FG}}$ & $2.57^{\mathrm{CDEF}}$ & $2.46^{\mathrm{CDEF}}$ & $2.49^{\mathrm{CDEF}}$ & $2.67^{\mathrm{CDE}}$ & $2.58^{\mathrm{CDEF}}$ & $2.45^{\mathrm{CDEF}}$ & $2.32^{\mathrm{EFG}}$ & $2.04^{\mathrm{G}}$ \\
\hline $\begin{array}{l}\text { PK : Pa } \\
\text { LK : Le } \\
\text { TK : Tir } \\
\text { LD : Lir } \\
\text { DD : De }\end{array}$ & $\begin{array}{l}\text { ang Kepala } \\
\text { ar Kepala } \\
\text { gi Kepala } \\
\text { kar Dada } \\
\text { Im Dada }\end{array}$ & & & $\begin{array}{l}\text { LeD : Lebar I } \\
\text { R-U : Radius } \\
\text { Hu : Humerus } \\
\text { Ti : Tibia } \\
\text { Fe : Femur }\end{array}$ & $\begin{array}{l}\text { ada } \\
\text { Jlna }\end{array}$ & & $\begin{array}{l}\mathrm{T} \\
\mathrm{L} \\
\mathrm{D} \\
\mathrm{L} \\
\mathrm{B}\end{array}$ & $\begin{array}{l}\text { Panjang Puı } \\
\text { : Lebar Pang } \\
\text { : Panjang T } \\
\text { : Lebar Teliı } \\
\text { : Bobot Bad }\end{array}$ & $\begin{array}{l}\text { gung } \\
\text { ul } \\
\text { nga } \\
\text { a }\end{array}$ & \\
\hline
\end{tabular}

Ukuran tubuh yang lebih kecil ditunjukkan oleh Rex dan Dwarfth namun mempunyai ukuran lingkar dada relatif besar sehingga terlihat kokoh dan kompak, hal ini merupakan ekspresi fenotipik yang dipengaruhi oleh faktor genetik ternak dengan ukuran yang spesifik sesuai dengan galurnya.

Ukuran dan bentuk tubuh yang medium pada kelinci Lop, Lyon, AI, dan AF namun setiap galur memberikan ciri fenotip yang berbeda dengan galur kelinci lainnya. Kelinci Lop terlihat ukuran tubuh yang relatif pendek namun kokoh dan kompak, sedangkan pada Lyon, AI, dan AF bentuk tubuh yang relatif panjang dan ramping. 


\section{Karakteristik Panjang Bulu Kelinci}

Tabel 2a. Karakteristik panjang bulu kelinci AI, AF, Lyang, Lyalya, Angrexlya, Lyplyp, ES, Lop, Lyon, Loplylo.

\begin{tabular}{|c|c|c|c|c|c|c|c|c|c|c|}
\hline \multirow[t]{2}{*}{ Peubah } & \multicolumn{10}{|c|}{ Galur kelinci } \\
\hline & AI & $\mathrm{AF}$ & lyang & Lyalya & Angrexlya & Lyplyp & ES & Lop & Lyon & Loplylo \\
\hline $\mathrm{BP}$ & $8.1327^{\mathrm{A}}$ & $8.6995^{A}$ & $5.6166^{\mathrm{B}}$ & $5.1703^{\mathrm{BC}}$ & $4.6900^{\mathrm{BCD}}$ & $4.1440^{\mathrm{BCD}}$ & $4.1430^{\mathrm{BCD}}$ & $4.0743^{\mathrm{BCD}}$ & $4.0702^{\mathrm{BCD}}$ & $4.0695^{\mathrm{BCD}}$ \\
\hline $\mathrm{BPG}$ & $9.2538^{\mathrm{A}}$ & $8.4374^{\mathrm{AB}}$ & $7.7776^{\mathrm{ABC}}$ & $9.1585^{\mathrm{A}}$ & $6.9148^{\mathrm{BCD}}$ & $6.0520^{\mathrm{CDE}}$ & $4.7781^{\mathrm{DEF}}$ & $4.6512^{\mathrm{DEF}}$ & $8.0978^{\mathrm{ABC}}$ & $5.1808^{\mathrm{DEF}}$ \\
\hline BTT & $11.346^{\mathrm{A}}$ & $6.119^{\mathrm{AB}}$ & $8.240^{\mathrm{AB}}$ & $7.860^{\mathrm{AB}}$ & $7.755^{\mathrm{AB}}$ & $8.033^{\mathrm{AB}}$ & $6.312^{\mathrm{AB}}$ & $7.158^{\mathrm{AB}}$ & $8.466^{\mathrm{AB}}$ & $7.511^{\mathrm{AB}}$ \\
\hline BTK & $6.5455^{\mathrm{AB}}$ & $7.2624^{\mathrm{A}}$ & $4.0215^{\mathrm{CDE}}$ & $4.7132^{\mathrm{BC}}$ & $4.1923^{\mathrm{CD}}$ & $3.6315^{\mathrm{CDEF}}$ & $2.1081^{\mathrm{DEF}}$ & $2.8862^{\mathrm{CDEF}}$ & $4.1346^{\mathrm{CDE}}$ & $2.6475^{\mathrm{CDEF}}$ \\
\hline BPRT & $7.7035^{\mathrm{A}}$ & $7.5125^{\mathrm{AB}}$ & $6.8719^{\mathrm{AB}}$ & $8.2257^{\mathrm{A}}$ & $6.8905^{\mathrm{AB}}$ & $4.3820^{\mathrm{CDE}}$ & $4.1333^{\mathrm{CDE}}$ & $4.6040^{\mathrm{CDE}}$ & $5.8315^{\mathrm{BC}}$ & $4.9188^{\mathrm{CD}}$ \\
\hline
\end{tabular}

Tabel 2b. Karakteristik panjang bulu kelinci VR, Loes, Lilolop, Anglolylo, Lilo, Lorex, Lovla, Lela, Dwarfth, Rex.

\begin{tabular}{|c|c|c|c|c|c|c|c|c|c|c|}
\hline \multirow[t]{2}{*}{ peubah } & \multicolumn{10}{|c|}{ Galur kelinci } \\
\hline & VR & loes & lilolop & Anglolylo & lilo & lorex & lovla & lela & dwarfth & rex \\
\hline $\mathrm{BP}$ & $4.0045^{\mathrm{BCD}}$ & $3.9008^{\mathrm{BCDE}}$ & $3.8343^{\mathrm{BCDE}}$ & $3.7642^{\mathrm{BCDE}}$ & $3.7434^{\mathrm{BCDE}}$ & $3.5673^{\mathrm{CDE}}$ & $3.4910^{\mathrm{CDE}}$ & $3.1953^{\mathrm{DE}}$ & $2.94^{\mathrm{DE}}$ & $2.0612^{\mathrm{E}}$ \\
\hline BPG & $4.6147^{\mathrm{EF}}$ & $4.1295^{\mathrm{EFG}}$ & $4.8230^{\mathrm{DEF}}$ & $5.0628^{\mathrm{DEF}}$ & $.8704^{\mathrm{DEF}}$ & $3.9877^{\mathrm{EFG}}$ & $3.9708^{\mathrm{EFG}}$ & $5.0123^{\mathrm{DEF}}$ & $3.4503^{\mathrm{FG}}$ & $2.1816^{\mathrm{G}}$ \\
\hline BTT & $3.658^{\mathrm{AB}}$ & $3.049^{\mathrm{B}}$ & $8.465^{\mathrm{AB}}$ & $6.996^{\mathrm{AB}}$ & $6.676^{\mathrm{AB}}$ & $2.806^{\mathrm{B}}$ & $2.936^{\mathrm{B}}$ & $8.372^{\mathrm{AB}}$ & $2.271^{\mathrm{B}}$ & $1.741^{\mathrm{B}}$ \\
\hline BTK & $2.1293^{\mathrm{DEF}}$ & $1.9389^{\mathrm{DEF}}$ & $2.2750^{\mathrm{DEF}}$ & $2.9698^{\mathrm{CDEF}}$ & $2.7372^{\mathrm{CDEF}}$ & $1.8399^{\mathrm{EF}}$ & $2.0815^{\mathrm{DEF}}$ & $2.8863^{\mathrm{CDEF}}$ & $1.5900^{\mathrm{F}}$ & $1.3256^{\mathrm{F}}$ \\
\hline BPRT & $4.0108^{\mathrm{CDEF}}$ & $3.3698^{\mathrm{DEF}}$ & $4.0260^{\mathrm{CDEF}}$ & $3.7772^{\mathrm{DEF}}$ & $4.3317^{\mathrm{CDE}}$ & $3.1641^{\mathrm{DEF}}$ & $3.5592^{\mathrm{DEF}}$ & $4.5247^{\mathrm{CDE}}$ & $2.9210^{\mathrm{EF}}$ & $2.2308^{\mathrm{F}}$ \\
\hline
\end{tabular}

Keterangan: Huruf superskrip yang berbeda pada baris yang sama, berbeda nyata $(\mathrm{P}<0,05)$.

Hasil uji Duncan terhadap pengukuran panjang bulu pada Tabel 2a dan 2b menunjukkan kelinci yang dipelihara karena keindahan bulunya seperti AI, AF dan Lyon terlihat lebih panjang dari kelinci lainnya yang ditunjukkan oleh notasi huruf pada rataan setiap peubah, namun perbedaan bulu AI dan Lyon pada bulu punggung dan bulu kepala diantara mata, pada AI berturut-turut adalah $(8,1327 \mathrm{~cm})$ dan $(6,5455 \mathrm{~cm})$, sedangkan pada Lyon adalah $(4,0702 \mathrm{~cm})$ dan $(4,1346 \mathrm{~cm})$.

Menurut Putra dan Budiana (2006) AF pada bagian wajahnya tidak memiliki bulu yang panjang serta telinganya juga tidak memiliki rumbai kebawah (menjutai kebawah), berbeda dengan AF yang ada di peternakan Rehna Latersia yang memiliki ukuran bulunya yang cukup panjang pada bagian diantara telinga $(6,119 \mathrm{~cm})$ dan mata $(7.2624 \mathrm{~cm})$, hal ini diduga diakibatkan karena terjadinya persilangan dengan kelinci lain, dan terlihat pola perkawinan yang kurang diperhatikan atau kekurangan pejantan yang sejenis sehingga terpaksa disilangkan dengan kelinci jenis lain.

Uji Duncan terhadap rataan ukuran panjang bulu dapat diketahui tujuan produksi peternak adalah sebagai kelinci hias terlihat dari banyaknya galur kelinci disilangkan dengan kelinci Angora dan Lyon dengan tujuan mendapatkan bulu yang panjang yang banyak diminati 
oleh pembeli sebagai kelinci hias. Berbeda dengan kelinci Dwarfth dan Rex yang disukai karena warna bulu dan kehalusannya terutama pada kelinci Rex yang mempunyai panjang bulu yang merata dan seperti beludru.

\section{Analisis Diskriminan Pada Kelinci}

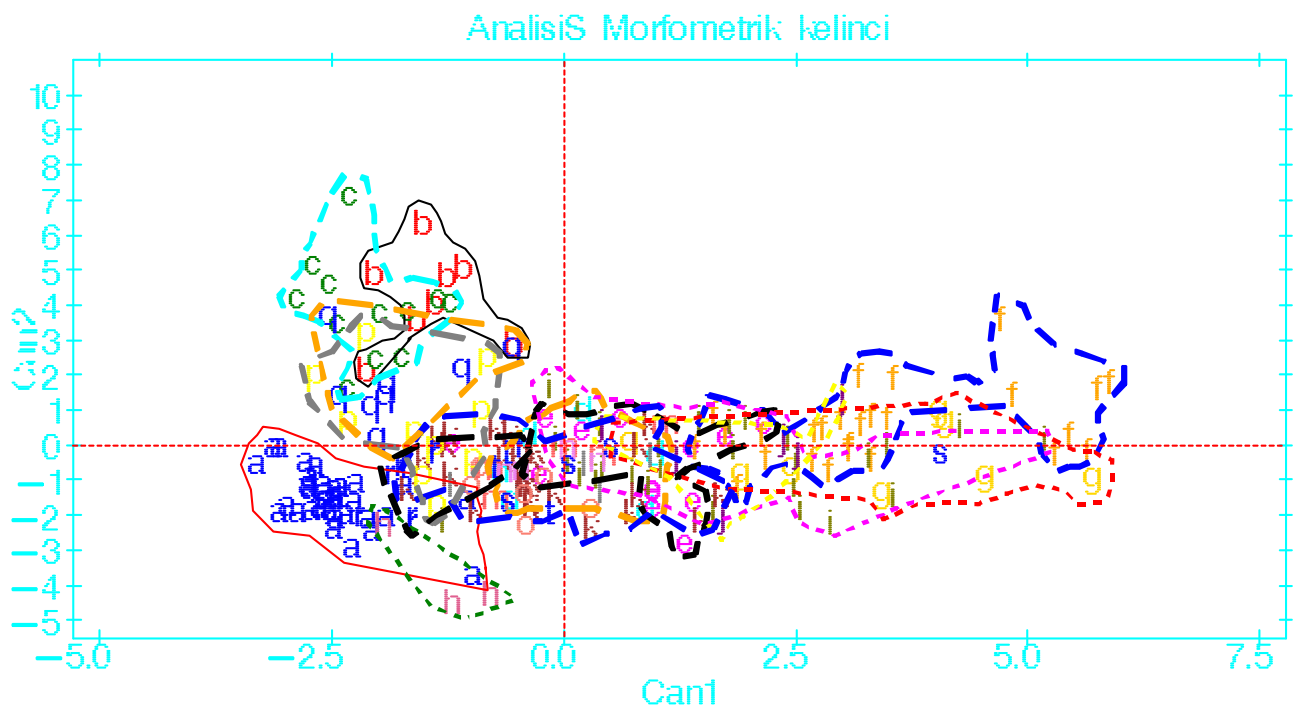

Gambar 1. Peta penyebaran kelinci menurut ukuran fenotipik, kelinci rex (a), english spot (b), vlaamse reus (c), lop (d), lyon (e), angora inggris (f), angora perancis (g), dwarfth (h), lyang (i), lyalya (j), lilo (k), lyplyp (l), loplylo (m), lilolop (n), anglolylo (o), lovla (p), loes (q), lorex (r), angrexlya (s), lela (t).

Analisis diskriminan digunakan untuk mengklasifikasikan individu-individu kedalam dua atau lebih kelompok (populasi) berdasarkan pengukuran-pengukuran tertentu (Afifi et al., 1996)

Hasil analisis diskriminan menunjukkan bahwa secara morfologis adanya perbedaan dan persamaan bentuk dan ukuran tubuh antar galur kelinci dengan adanya garis pemisah dan adanya irisan antar galur kelinci (Gambar 1). Berdasarkan gambar tersebut, kelinci Rex dan kelinci Dwarfth dengan ukuran tubuh relatif kecil dan ukuran rambut yang pendek terlihat mengelompok dan tersebar disebelah kiri axis $\mathrm{Y}$ dibawah axis $\mathrm{X}$ memperlihat kan penampilan fenotipik yang berbeda dibandingkan kelinci lainnya, sedangkan kelinci english ES dan VR sebagai kelinci dengan ukuran tubuh paling besar dipopulasi menyebar disebelah kiri axis Y diatas axis X. Gambaran sebaran ini mencirikan bahwa kelinci ES dan VR memiliki ukuran 
fenotipik yang berbeda secara relatif dengan kelinci rex dan dwarfth dengan tidak adanya irisan pada peta penyebaran.

Dengan irisan yang cukup besar pada peta penyebaran yang diperlihatkan oleh AI dan AF menggambarkan banyaknya kesamaan bentuk dan ukuran tubuh antara kelinci AI dan AF artinya secara morfologis bahwa hubungan genetik diantara kedua rumpun ini cukup dekat begitupun dengan kelinci silangan juga beririsan dengan tetuanya.

Secara keseluruhan galur kelinci berkumpul di axis $\mathrm{X}$ dengan banyaknya irisan antar kerumunan, hal ini menunjukkan tingkat persilangan antar galur sangat tinggi dan berada pada populasi dan lingkungan yang sama baik itu pakan, dan menejemen pemeliharaan yang dapat mempengaruhi ukuran tubuh kelinci-kelinci tersebut.

\section{Nilai Kesamaan dan Campuran Antar Galur Kelinci}

Hasil analisis fungsi diskriminan terhadap ukuran tubuh dan karakteristik panjang rambut antar galur kelinci menghasilkan pengelompokkan berdasarkan persentase nilai kesamaan dan campuran didalam galur antar galur sebagaimana disajikan pada Tabel 3. Dari tabel tersebut dapat diduga adanya nilai kesamaan pada suatu galur dengan kemungkinan besarnya proporsi nilai campuran yang mempengaruhi kesamaan satun galur dengan galur lainnya berdasarkan atas persamaan ukuran dan bentuk tubuh dan panjang rambut hasil pengelompokan ini juga menggambarkan persentase kemurnian setiap galur kelinci.

Kesamaan ukuran tubuh di dalam galur dari yang tinggi ke yang rendah berturut-turut kelinci Dwarfth (100\%), Rex (88,89\%), ES (87,50\%), VR (83,33\%), Lorex $(77,78 \%)$, Loes (75,00\%), Lilolop (75,00\%), Lela (66,67\%), Anglolylo (66,67\%), AF (62,50\%), Lyon (61,54\%), AI (53,85\%), Lop (50,00\%), Lovla (50,00\%), Lyalya (50,00\%), Lyplyp (50,00\%), Lilo (40,74\%), Loplylo (33,33\%), Angrexlya (25,00\%) dan Lyang (17,86\%).

Berdasarkan hasil analisis diskriminan menunjukkan bahwa kelinci Dwarfth tidak ada tercampur dengan kelinci lain sedangkan kelinci Rex sedikit tercampur dengan Lovla (5,56 \%) dan Lorex $(2,78 \%)$, tidak adanya pencampuran kelinci lain terhadap Dwarfth dan rendahnya pencampuran kelinci Lovla terhadap Rex terjadi karena perbedaan tujuan produksi dan perkawinan yang dilakukan hanya sesama Rex dan sesama Dwarfth dengan keinginan menyediakan kelinci dengan fenotipik yang beragam untuk memberikan pilihan bagi konsumen, sehingga kelinci Dwarfth karakternya lebih spesifik sebagai kelinci ukuran kecil dengan pola warna yang unik begitu juga dengan kelinci Rex lebih spesifik menunjukkan ukuran dan bentuk tubuh yang kompak dengan bulu yang halus seperti beludru dengan panjang yang merata dan sangat khas. 
Kelinci VR dipengaruhi oleh kelinci Lovla (8,33 \%) dan kelinci Loes $(8,33 \%)$ sedangkan kelinci Lovla dipengaruhi oleh kelinci ES (20\%), Loes (10\%), Lorex (20\%) dan tidak ada dipengaruhi oleh kelinci VR. Hal ini diduga kelinci Lovla merupakan kelinci Lokal namun mempunyai ukuran morfometrik yang besar dengan pola warna bulu menyerupai VR. Persamaan fenotipik ukuran tubuh dan panjang rambut berbagai galur kelinci merupakan cerminan dari besarnya campuran kelompok antar galur yang terjadi baik oleh adanya mutasi hasil rekayasa peternak maupun yang terjadi secara alamiah (Suparyanto et al., 1999).

Ukuran fenotipik yang saling mempengaruhi antar galur khususnya pada galur kelinci persilangan memperlihatkan tujuan produksi yang sama khususnya yang disilangkan dengan kelinci angora inggris, angora francis, lyon dan lop. Terlihat indikasi kelinci tersebut cenderung memiliki kesamaan morfologi yang diarahkan oleh peternak untuk memproduksi kelinci dengan ukuran rambut yang panjang demi dalam memenuhi permintaan yang lebih menyukai kelinci dengan rambut yang panjang di daerah Berastagi. 
Tabel 3 .Nilai kesamaan dan campuran galur kelinci

\begin{tabular}{|c|c|c|c|c|c|c|c|c|c|c|c|c|c|c|c|c|c|c|c|c|c|}
\hline Galur & Anglolylo & $\overline{\mathrm{AF}}$ & $\mathrm{AI}$ & Angrexlya & Dwarftl & ES & Lela & Lilo & Lilolop & Loes & Lop & Loplylo & Lorex & Lovla & Lyalya & Lyang & Lyon & Lyplyp & $\operatorname{Rex}$ & VR & Total \\
\hline Anglolylo & 66,67 & 0,00 & 0,00 & 0,00 & 0,00 & 0,00 & 0,00 & 0,00 & 0,00 & 0,00 & 16,67 & 0,00 & 16,67 & 0,00 & 0,00 & 0,00 & 0,00 & 0,00 & 0,00 & 0,00 & 100 \\
\hline $\mathrm{AF}$ & 0,00 & 62,50 & 12,50 & 0,00 & 0,00 & 0,00 & 0,00 & 0,00 & 0,00 & 0,00 & 0,00 & 0,00 & 0,00 & 0,00 & 12,50 & 12,50 & 0,00 & 0,00 & 0,00 & 0,00 & 100 \\
\hline AI & 0,00 & 23,08 & 53,85 & 7,69 & 0,00 & 0,00 & 0,00 & 0,00 & 0,00 & 0,00 & 0,00 & 0,00 & 0,00 & 0,00 & 7,69 & 7,69 & 0,00 & 0,00 & 0,00 & 0,00 & 100 \\
\hline Angrexlya & 0,00 & 0,00 & 0,00 & 25,00 & 0,00 & 0,00 & 0,00 & 0,00 & 0,00 & 0,00 & 0,00 & 50,50 & 0,00 & 0,00 & 25,00 & 0,00 & 0,00 & 0,00 & 0,00 & 0,00 & 100 \\
\hline Dwarfth & 0,00 & 0,00 & 0,00 & 0,00 & 100 & 0,00 & 0,00 & 0,00 & 0,00 & 0,00 & 0,00 & 0,00 & 0,00 & 0,00 & 0,00 & 0,00 & 0,00 & 0,00 & 0,00 & 0,00 & 100 \\
\hline ES & 0,00 & 0,00 & 0,00 & 0,00 & 0,00 & 87,50 & 0,00 & 0,00 & 0,00 & 12,50 & 0,00 & 0,00 & 0,00 & 0,00 & 0,00 & 0,00 & 0,00 & 0,00 & 0,00 & 0,00 & 100 \\
\hline Lela & 0,00 & 0,00 & 0,00 & 0,00 & 0,00 & 0,00 & 66.67 & 0,00 & 0,00 & 0,00 & 0,00 & 0,00 & 0,00 & 0,00 & 0,00 & 0,00 & 0,00 & 33,33 & 0,00 & 0,00 & 100 \\
\hline Lilo & 3,70 & 0,00 & 0,00 & 11,11 & 3,70 & 0,00 & 3,70 & 40,74 & 3,70 & 0,00 & 7,41 & 7,41 & 7,41 & 0,00 & 3,70 & 0,00 & 7,41 & 0,00 & 0,00 & 0,00 & 100 \\
\hline Lilolop & 0,00 & 0,00 & 0,00 & 0,00 & 0,00 & 0,00 & 0,00 & 0,00 & 75,00 & 0,00 & 0,00 & 0,00 & 0,00 & 0,00 & 0,00 & 0,00 & 0,00 & 25,00 & 0,00 & 0,00 & 100 \\
\hline Loes & 0,00 & 0,00 & 0,00 & 0,00 & 0,00 & 12,50 & 0,00 & 0,00 & 0,00 & 75,00 & 0,00 & 0,00 & 0,00 & 0,00 & 0,00 & 0,00 & 0,00 & 0,00 & 12,50 & 0,00 & 100 \\
\hline Lop & 16,67 & 0,00 & 0,00 & 0,00 & 0,00 & 0,00 & 0,00 & 16,67 & 0,00 & 0,00 & 50,00 & 0,00 & 16,67 & 0,00 & 0,00 & 0,00 & 0,00 & 0,00 & 0,00 & 0,00 & 100 \\
\hline Loplylo & 16,67 & 0,00 & 0,00 & 16,67 & 0,00 & 0,00 & 0,00 & 16,67 & 0,00 & 0,00 & 0,00 & 33,33 & 0,00 & 16,67 & 0,00 & 0,00 & 0,00 & 0,00 & 0,00 & 0,00 & 100 \\
\hline Lorex & 0,00 & 0,00 & 0,00 & 0,00 & 0,00 & 0,00 & 0,00 & 0,00 & 0,00 & 0,00 & 0,00 & 0,00 & 77,78 & 0,00 & 0,00 & 0,00 & 0,00 & 11,11 & 11,11 & 0,00 & 100 \\
\hline Lovla & 0,00 & 0,00 & 0,00 & 0,00 & 0,00 & 20,00 & 0,00 & 0,00 & 0,00 & 10,00 & 0,00 & 0,00 & 20,00 & 50,00 & 0,00 & 0,00 & 0,00 & 0,00 & 0,00 & 0,00 & 100 \\
\hline Lyalya & 0,00 & 0,00 & 0,00 & 16,67 & 0,00 & 0,00 & 0,00 & 16,67 & 0,00 & 0,00 & 0,00 & 0,00 & 0,00 & 0,00 & $\mathbf{5 0 , 0 0}$ & 0,00 & 16,67 & 0,00 & 0,00 & 0,00 & 100 \\
\hline Lyang & 0,00 & 0,00 & 14,29 & 14,29 & 0,00 & 0,00 & 7,14 & 10,71 & 0,00 & 0,00 & 0,00 & 3,57 & 0,00 & 3,57 & 14,29 & 17,86 & 10,71 & 3,57 & 0,00 & 0,00 & 100 \\
\hline Lyon & 7,69 & 0,00 & 0,00 & 7,69 & 0,00 & 0,00 & 0,00 & 7,69 & 0,00 & 7,69 & 0,00 & 7,69 & 0,00 & 0,00 & 0,00 & 0,00 & 61,54 & 0,00 & 0,00 & 0,00 & 100 \\
\hline Lyplyp & 0,00 & 0,00 & 0,00 & 0,00 & 0,00 & 0,00 & 0,00 & 0,00 & 0,00 & 0,00 & 25,00 & 0,00 & 25,00 & 0,00 & 0,00 & 0,00 & 0,00 & 50,00 & 0,00 & 0,00 & 100 \\
\hline Rex & 0,00 & 0,00 & 0,00 & 0,00 & 2,78 & 0,00 & 0,00 & 0,00 & 0,00 & 0,00 & 0,00 & 0,00 & 2,78 & 5,56 & 0,00 & 0,00 & 0,00 & 0,00 & 88,89 & 0,00 & 100 \\
\hline VR & 0,00 & 0,00 & 0,00 & 0,00 & 0,00 & 0,00 & 0,00 & 0,00 & 0,00 & 8,33 & 0,00 & 0,00 & 0,00 & 8,33 & 0,00 & 0,00 & 0,00 & 0,00 & 0,00 & 83,33 & 100 \\
\hline Total & 3,52 & 4,85 & 8,37 & 5,73 & 2,20 & 4,41 & 2,20 & 7,93 & 1,76 & 4,41 & 3,08 & 3,52 & 6,61 & 4,41 & 5,29 & 3,52 & 6,17 & 2,64 & 14,98 & 4,41 & 100 \\
\hline
\end{tabular}




\section{Jarak Genetik dan Pohon Fenogram}

Jarak genetik adalah perselisihan genetik antara spesies atau antara populasi dalam satu spesies tertentu. Jarak genetik diukur dengan berbagai parameter. Jarak genetik yang kecil menunjukkan hubungan genetik yang dekat dan sebaliknya, jarak genetik yang besar menunjukkan hubungan genetik yang jauh.

Jarak genetik dapat digunakan untuk membandingkan persamaan genetik antara spesies yang berbeda, seperti misalnya manusia dan simpanse. Dalam satu spesies tertentu, jarak genetik dapat digunakan untuk mengukur perselisihan antara subspesies yang berbeda (Wikipedia, 2012).

Pohon fenogram menggambarkan hubungan silsilah antar organisme atau populasi dalam sebuah diagram. Pohon fenogram menyajikan gambar yang mewakili aliran evolusi dari spesies atau individu yang lebih dahulu sampai spesies atau populasi yang terbaru (Wiley, 1981).

Nilai jarak genetik antar galur kelinci yang disajikan pada Tabel 4 digunakan untuk membuat konstruksi pohon fenogram (Gambar 3). Pohon fenogram menggambarkan jarak genetik keseluruhan antara galur kelinci. Berdasarkan nilai jarakgenetiknya, kelinci Lop dan Loplylo memiliki nilai yang terkecil (1,66), kelinci Lyon dengan Lyang (1,98), Lilo dengan Anglolylo (1,79), Lyang dengan Angrexlya (1,86), Loplylqo dengan Lilo (1,31), Lyplyp dengan Lilo (1,59), Lovla dengan Loes (1,89), Lyplyp dengan Loplylo (1,93). Jarak genetik yang jauh diperlihatkan oleh kelinci ES dengan Dwarfth (8,28), VR dengan AF (7,23), ES dengan AF $(7,15)$, Dwarfth dengan AI (7,04), Dwarfth dengan AF (6,71), Lop dengan ES (5,32 ), ES dengan Rex (6,14), VR dengan Rex (5,76). Hal ini sesuai dengan yang dikemukakan oleh Brahmantiyo (2006) bahwa kelinci di Magelang memiliki jarak genetik yang cukup dekat pada ES dan VR namun cukup jauh dengan kelinci Rex.

Jarak genetik yang jauh 8,41 (VR - Dwarfth), 8,28 (ES-Dwarfth), 7,23 (VR-AF), 7,15 (ES- AF), 6,47 (VR-AI), 6,13 (ES- AI), 7,04 (Dwarfth-AI), 6,71 (Dwarfth-angora Francis), 5,30 (Dwarfth-Lop), 6,26 (Rex-AI). Hasil ini sangat mendukung peta penyebaran galur kelinci (Gambar 2) dimana galur kelinci mengelompok berdasarkan ukuran tubuh dan panjang rambut. Jarak genetik yang dekat antar silangan dan tetuanya juga mendukung peta penyebaran galur kelinci dimana terjadi irisan antar galur silangan dengan tetuanya yang menandakan adanya kesamaan ukuran dan bentuk tubuh dan ukuran panjang rambut. Jarak genetik yang dekat 3,04 (Loes-ES), 3,76 (Lovla-VR), 1,31 (Lilo-Loplylo), 1,66 (Lop-Loplylo), 1,98 (Lyang-Lyon), 1,93 
(Lyplyp-Loplylo), 1,79 (Lilo-Anglolylo) pada peta penyebaran terjadi irisan antar kerumunan berdasarka ukuran dan bentuk dan ukuran panjang rambut setiap galur kelinci.

Ukuran jarak genetik yang relatif dekat jika disilangkan tidak akan mendapatkan kemajuan ukuran kuantitatif yang mengesankan karena sifat heterosis yang didapat lebih banyak berasal dari keragaman dalam bangsa sedangkan jarak genetik yang relatif jauh jika disilangkan diharapkan sifat heterosis yang muncul dari keragaman antar bangsa yang disilangkan sehingga kemajuan genetik dengan keragaman genetik yang tinggi dapat diperoleh.

Persilangan antara galur kelinci dengan jarak genetik yang relatif dekat pada populasi meningkatkan peluang akan terjadinya inbreeding yang pada taraf tertentu atau intensitas inbreeding yang tinggi justru akan menurunkan sifat-sifat produksi dan menurunkan tingkat keragaman sifat-sifat kuantitatif dengan meningkatnya gen yang homozigot. 
Tabel 4. Jarak genetik antar galur kelinci

\begin{tabular}{|c|c|c|c|c|c|c|c|c|c|c|c|c|c|c|c|c|c|c|c|c|}
\hline Galur & Anglolylo & $\mathrm{AF}$ & AI & Angrexlya & Dwarfth & $\mathrm{ES}$ & Lela & Lilo & Lilolop & Loes & Lop & Loplylo & Lorex & Lovla & Lyalya & Lyang & Lyon & Lyplyp & $\operatorname{Rex}$ & VR \\
\hline Anglolylo & 0 & & & & & & & & & & & & & & & & & & & \\
\hline Af & 5.10 & 0 & & & & & & & & & & & & & & & & & & \\
\hline $\mathrm{Ai}$ & 4.53 & 2.38 & 0 & & & & & & & & & & & & & & & & & \\
\hline Angrexlya & 3.17 & 4.08 & 3.37 & 0 & & & & & & & & & & & & & & & & \\
\hline Dwarfth & 4.93 & 6.71 & 7.04 & 5.07 & 0 & & & & & & & & & & & & & & & \\
\hline Es & 6.08 & 7.15 & 6.13 & 5.59 & 8.28 & 0 & & & & & & & & & & & & & & \\
\hline Lela & 3.41 & 5.08 & 4.95 & 3.30 & 4.72 & 5.55 & 0 & & & & & & & & & & & & & \\
\hline Lilo & 1.79 & 4.62 & 4.25 & 2.43 & 4.50 & 5.35 & 2.82 & 0 & & & & & & & & & & & & \\
\hline Lilolop & 3.35 & 5.32 & 4.97 & 3.65 & 5.44 & 5.20 & 4.18 & 2.32 & 0 & & & & & & & & & & & \\
\hline Loes & 3.77 & 6.01 & 5.31 & 4.24 & 6.35 & 3.04 & 3.90 & 3.25 & 3.79 & 0 & & & & & & & & & & \\
\hline Lop & 2.02 & 4.82 & 4.11 & 2.93 & 5.30 & 5.32 & 3.47 & 1.92 & 3.31 & 3.54 & 0 & & & & & & & & & \\
\hline Loplylo & 2.10 & 4.65 & 4.08 & 2.34 & 4.94 & 5.19 & 2.94 & 1.31 & 3.15 & 3.08 & 1.66 & 0 & & & & & & & & \\
\hline Lorex & 2.22 & 5.48 & 5.33 & 3.55 & 4.45 & 5.64 & 2.91 & 2.22 & 3.21 & 3.25 & 2.59 & 2.42 & 0 & & & & & & & \\
\hline Lovla & 3.15 & 5.65 & 5.11 & 3.59 & 5.44 & 3.84 & 2.96 & 2.82 & 3.72 & 1.89 & 3.08 & 2.73 & 2.67 & 0 & & & & & & \\
\hline Lyalya & 4.05 & 4.25 & 3.53 & 2.91 & 6.46 & 5.99 & 4.58 & 3.49 & 4.04 & 4.75 & 4.04 & 3.48 & 4.75 & 4.75 & 0 & & & & & \\
\hline Lyang & 3.21 & 3.23 & 2.66 & 1.86 & 5.43 & 5.57 & 3.08 & 2.41 & 3.52 & 4.17 & 2.93 & 2.31 & 3.62 & 3.75 & 2.23 & 0 & & & & \\
\hline Lyon & 2.68 & 4.52 & 3.61 & 2.21 & 5.24 & 5.49 & 3.19 & 2.19 & 3.36 & 3.89 & 2.83 & 2.38 & 3.38 & 3.56 & 2.61 & 1.98 & 0 & & & \\
\hline Lyplyp & 2.27 & 4.45 & 4.22 & 2.86 & 5.14 & 5.89 & 3.46 & 1.59 & 2.77 & 3.75 & 2.58 & 1.93 & 2.60 & 3.52 & 3.63 & 2.61 & 2.35 & 0 & & \\
\hline $\operatorname{Rex}$ & 2.75 & 6.49 & 6.26 & 4.17 & 4.11 & 6.14 & 2.94 & 2.94 & 4.25 & 3.85 & 3.29 & 3.21 & 2.23 & 2.84 & 5.60 & 4.53 & 4.06 & 3.75 & 0 & \\
\hline $\mathrm{Vr}$ & 5.73 & 7.23 & 6.47 & 5.91 & 8.41 & 2.88 & 5.39 & 5.23 & 5.63 & 2.62 & 5.09 & 4.87 & 5.20 & 3.76 & 6.09 & 5.69 & 5.61 & 5.46 & 5.76 & 0 \\
\hline
\end{tabular}




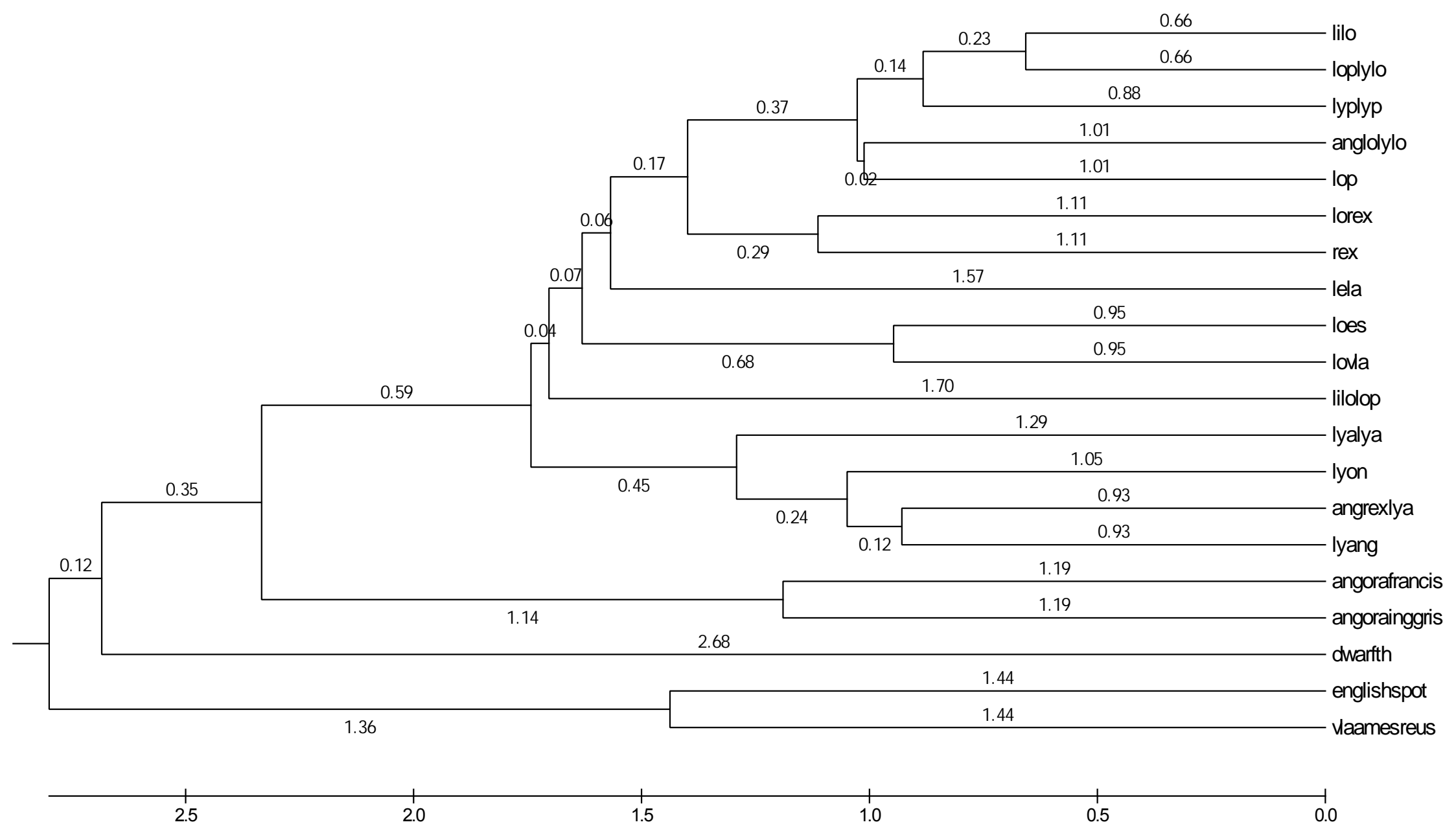

Skala jarak genetik kelinci berdasarkan morfometrik.

Gambar 2. Pohon fenogram kelinci 
Pohon fenogram (Gambar 2) menunjukkan bahwa galur kelinci Lilo dekat dengan Loplylo, Lyplyp, Anglolylo, dan Lop. Hal ini mendukung kajian sebelumnya pada sub bab (nilai kesamaan dan campuran) yang menyatakan tingginya nilai campuran Loplylo, Anglolylo dan Lop terhadap kelinci Lilo, sehingga membentuk hubungan kekerabatan yang cukup dekat, begitu juga dengan kelinci Angrexlya, Lyang, Lyon dan Lyalya membentuk hubungan kekerabatan yang relatif dekat .

Kelinci Lilolop yang pada silsilah nya mempunyai garis keturunan dari kelinci Lyon dan Lop mengelompok sendiri dengan kekerabatan yang relatif jauh terhadap kelinci Lyon dan kelinci Lop, hal ini diakibatkan Lilolop merupakan keturunan jauh dari Lyon dan Lop dan persilangan yang terjadi hanya terjadi sesama kelinci Lilolop yang dapat meningkatkan gen yang homozigot, tanpa adanya back cross terhadap kelinci Lop ataupun terhadap kelinci Lyon sehingga kelinci Lilolop sudah memilik atau membentuki ukuran dan bentuk tubuh dan panjang rambut yang lebih spesifik dan relatif berbeda dengan galur lainnya, begitupun hal yang sama ditunjukkan galur kelinci Lela.

Hubungan kekerabatan dekat yang terjadi pada galur Lorex dengan Rex $(2,23)$, AI dan AF $(2,38)$, Loes dengan Lovla (1,89), Angrexlya dan Lyang $(1,86)$, Lovla dengan Loes $(1,89)$, dan Anglolylo dengan Lop (2,02). Berdasarkan nilai jarak genetiknya yang dekat bila persilangan akan dilakukan tidak akan mendapatkan kemajuan ukuran kuantitatif yang mengesankan apabila tidak disertai dengan seleksi yang ketat.

Pohon fenogram kelinci Dwarfth menunjukkan garis yang berbeda dengan kelinci ES, VR, AI, AF dan galur kelinci lainnya yang mengartikan hubungan kekerabatan kelinci Dwarfth dengan kelinci lainnya cukup jauh berdasarkan ukuran dan bentuk tubuh dan panjang rambut, hal ini dipengaruhi tingginya nilai kesaaman dan tidak adanya campuran galur lain terhadap kelinci Dwarfth. secara genetik kelinci Dwarfth bertipe kecil sedangkan ES dan VR bertipe besar menandakan berbeda secara genetik sehingga jarak genetiknya relatif jauh, jarak genetik dwarfth dengan ES adalah 8,28 sedangkan Dwarfth dengan VR 8,41. Untuk galur kelinci Dwarfth jika disilangkan dengan ES atau VR dapat diperoleh peningkatan ukuran tubuh dikarenakan jauhnya jarak genetik tersebut.

Hubungan kekerabatan yang ditunjukkan oleh pohon fenogram memperjelas bahwa adanya nilai campuran antar galur kelinci akan berpengaruh terhadap kedekatan hubungan kekerabatan dan memperlihatkan tujuan produksi yang mengarah kepada kelinci hias dengan 
karakteristik panjang rambut terlihat dengan hubungan kekerabatan kelinci silangan dekat dengan kelinci yang mempunyai fenotipik bulu yang panjang seperti kelinci AI, Lyon, dan AF.

\section{Peubah Pembeda Galur Kelinci}

Analisis variat kanonikal (Tabel 4) digunakan untuk mendapatkan kombinasi karakter yang membedakan secara keseluruhan dan dapat digunakan untuk menggambar plot skor guna membandingkan di dalam dan diantara variabilitas populasi (galur kelinci) pada dimensi yang kecil (Wiley,1981).

Analisa kanonik peubah bobot badan tidak disertakan karena dipengaruhi oleh lingkungan yang temporer khususnya yang diakibatkan oleh kondisi saat bunting dan kondisi saat baru melahirkan yang sangat mempengaruhi bobot badan, sedangkan untuk ilkim, pakan dan menejemen pemeliharaan untuk setiap galur kelinci mendapatkan perlakuan yang sama.

Tabel 4. Total Struktur Kanonik

\begin{tabular}{lcl}
\hline Peubah & Kanonik 1 & Kanonik 2 \\
\hline Panjang kepala & 0.078305 & 0.839608 \\
Lebar kepala & 0.008347 & 0.539624 \\
Tinggi kepala & -0.029619 & 0.701741 \\
Lingkar dada & -0.218685 & 0.434148 \\
Dalam dada & -0.070410 & 0.597292 \\
Lebar dada & -0.089826 & 0.431504 \\
Radius-ulna & 0.134803 & 0.571097 \\
Humerus & 0.119501 & 0.726223 \\
Tibia & 0.187303 & 0.693524 \\
Femur & 0.112658 & 0.554787 \\
Pjg. Tlg, punggung & -0.147387 & 0.484224 \\
Lebar panggul & 0.056298 & 0.670184 \\
Panjang telinga & 0.089907 & 0.898563 \\
Lebar telinga & 0.029704 & 0.727725 \\
Pjg. Bulu punggung & 0.849455 & 0.132646 \\
Pjg. Bulu pinggul & 0.871661 & 0.064124 \\
Pjg. Bulu diantara telinga & 0.456834 & 0.010517 \\
Pjg. Bulu diantara mata & 0.772284 & -0.023973 \\
Pjg. Bulu perut & 0.878923 & 0.051932 \\
\hline
\end{tabular}

Kanonik 1 diperoleh korelasi cukup tinggi pada peubah panjang bulu perut $(0,878923)$, panjang bulu pinggul (0,871661), panjang bulu punggung (0,849455), panjang bulu diantara mata $(0,772284)$. Pada kanonik 2 diperoleh panjang kepala (0.839608), panjang tulang humerus 
(0.726223), panjang telinga (0.898563), dengan demikian peubah panjang bulu perut, panjang bulu pinggul, panjang bulu diantara mata, panjang bulu punggung, panjang kepala, panjang tulang humerus dan panjang telinga dapat digunakan sebagai peubah pembeda antar galur kelinci.

Melihat skor yang tinggi pada peubah Panjang bulu perut, bulu pinggul, panjang bulu punggung dan panjang bulu diantara mata menggambarkan peternak memilih kelinci dengan penampilan fenotipik pada ukuran rambut dengan tujuan produksi sebagai kelinci hias. Kanonik 2 digunakan sebagai pelengkap peubah yang membedakan setiap galur kelinci.

\section{KESIMPULAN}

Berdasarkan analisis kanonikal peubah fenotipik pembeda jenis kelinci adalah panjang bulu perut, panjang bulu pinggul, panjang bulu diantara mata, panjang bulu punggung, panjang kepala, panjang tulang humerus dan panjang telinga dapat digunakan sebagai peubah pembeda antar galur kelinci.

Secara garis besar berdasarkan nilai campuran antar galur, peta penyebaran, jarak genetik dan hubungan kekerabatan yang ditunjukkan oleh pohon fenogram membentuk empat kelompok secara relatif yaitu kelompok Rex dengan Lorex, kelompok Dwarfth, kemudian ES, VR, Loes dan Lovla membentuk satu kelompok, kemudian kelompok terakhir yang terdiri dari AI, AF, Lyon, Lyang, Angrexlya, Lyalya, Lela, Lop, Anglolylo, Lyplyp, Loplylo, dan Lilo.

Berdasarkan nilai campuran dalam galur dan antar galur serta jarak genetik dari galur kelinci, membuktikan selama ini terjadi persilangan antar galur dan dengan tujuan produksi yang sama yaitu sebagai ternak hias.

\section{DAFTAR PUSTAKA}

Afifi, A.A. dan V. Clark. 1996. Computer-Aided Multivariate Analysis. $3^{\text {rd }}$ Edition. Chapman and Hall/CRC, New York.

Brahmantiyo, B., H. Martojo, S.S. Mansjoer dan Y.C. Raharjo, 2006. Pendugaan JarakGenetik Kelinci Melalui Analisis Morfometrik. JITV 11(3): 206-214.

Falconer, D. S. dan T. F. C. Mackay. 1996. Quantitative Genetics. $4{ }^{\text {th }}$ Edition. Longman Group Ltd., England. 
Hamdan.2005. Pengaruh seleksi jangka panjang terhadap ragam aditif dan kemajuan genetic beberapa sifat produksi puyuh. Sekolah Pasca Sarjana IPB.

Kumar S., K. Tamura, I.B. jakobsen, and M. Nei. 2001. MEGA2: Molecular Evolutionary Genetics Analysis Software. Arizona State University, Tempe, Arizona, USA.

Lidia, F. 2006. Karakteristik Sifat Kualitatif dan Kuantitatif Kelinci Flemish Giant, English Spot, dan Rex di Kabupaten Magelang. Skripsi. IPB Bogor.

Mahalovich, M. F. 2004. Coat Color Genetics Of The Flemish Giant. American Rabbit Breeders Asosiation.http//www.nffgrb.com/Articles/Article Genetics1.html. [Desember 2005].

Manly BFJ. 1989. Multivariate Statistical Methods. A Primer. London : Chapman and Hall Ltd.

Martojo H. 1992. Peningkatan Mutu Genetik Ternak. Depertemen Pendidikan dan Kebudayaan. Direktorat Jenderal Pendidikan Tinggi. Pusat Antar Universitas Bioteknologi. Bogor. Institut Pertanian Bogor.

Nei M. 1987. Molecular Evolutionary Genetic. Columbia University Press. USA.

Noor RR. 2004. Genetika Ternak. Jakarta. Penebar Swadaya.

Putra. G. M dan Budiana, N. S. 2006. Kelinci Hias. Penebar Swadaya. Jakarta.

Raharjo Y.C., D. Gultom, S. Iskandar and L.H. Prasetyo. 2001. Peningkatan Produktivitas, Mutu Produk Dan Nilai Ekonomi Kelinci Eksotis Melalui Pemuliaan Dan Nutrisi. Laporan Hasil Penelitian. Balitnak bekerjasama dengan Badan Litbang Pertanian, Proyek Pembinaan Kelembagaan Penelitian dan Pengembangan Pertanian/ ARMP-II. Bogor.

Sarwono., 2002. Kelinci Potong Dan Hias. Agromedia. Jakarta.

Taylor J, Freedman L, Oliver TJ, Mc Clueskey J. 1977. Morphometric distance between Australian wild rabbit population. Aust. J. Zool., 25:721-32.

Warwick EJ, Astuti JM, Hardjosubroto W. 1995. Pemuliaan Ternak. Yogyakarta: Gadjahmada University Press.

Wikipedia, 2010. Jarak_Genetik, http://id.wikipedia.org/wiki/ [23 April 2013]

Wiley EO. 1981. Phylogenetics: The Theory and Practice Phylogenetic Systematic. Canada: John Wiley and Sons Inc 